\title{
Hubungan Pola Asuh Demokratis dan Intensitas Penggunaan Gawai pada Anak Usia Dini
}

\author{
Kadek Hengki Primayana ${ }^{{ }_{1}}$, Putu Yulia Angga Dewi ${ }^{2}$ \\ Pendidikan Guru Pendidikan Anak Usia Dini, Sekolah Tinggi Agama Hindu Negeri Mpu \\ Kuturan Singaraja \\ DOI: $\underline{10.31004 / \text { obsesi.v5i1.697 }}$
}

\begin{abstract}
Abstrak
Pola asuh orang tua terhadap anaknya mendasari penggunaan gawai. Orang tua yang menerapkan pola asuh demokratis memberikan gawai sejak dini pada anaknya. Penelitian ini bertujuan untuk mengetahui hubungan antara pola asuh demokratis dan intensitas penggunaan gawai. Dalam penelitian ini, metode yang digunakan adalah metode korelasi dan ex post facto. Data yang dikumpulkan menggunakan kuesioner dan untuk menguji hipotesis menggunakan teknik korelasi product moment. Hasil perhitungan penelitian ini menunjukkan bahwa $\mathrm{r}$ hitung lebih besar dari $\mathrm{r}$ tabel $(0,471>0,179)$. Berdasarkan hasil penelitian, dapat disimpulkan bahwa ada hubungan positif dan signifikan antara pola asuh demokratis dan intensitas penggunaan gawai oleh anak. Orang tua akan lebih lebih kreatif dalam mengasuh anak serta memberikan waktu pendampingan anak dalam bermain. Gawai memang dibutuhkan untuk sarana komunikasi namun perlu diatur intensitas penggunaanya.
\end{abstract}

Kata Kunci: pola asuh; gawai; teknologi; anak usia dini.

\begin{abstract}
The parenting style for their children underlies the use of gadgets. Parents who apply democratic parenting provide gadgets to their children from an early age. This study aims to determine the relationship between democratic parenting and the intensity of using gadgets. In this study, the method used is the correlation method and ex post facto. The data were collected using a questionnaire and to test the hypothesis using the product-moment correlation technique. The calculation results of this study indicate that the $r$ count is greater than $r$ table $(0.4714>0.179)$. Based on the research results, it can be concluded that there is a positive and significant relationship between democratic parenting and the intensity of the use of gadgets by children. Parents will be more creative in caring for children and give time to assist children in playing. Gadgets are needed for a means of communication but the intensity of their use needs to be regulated.
\end{abstract}

Keywords: parenting; gadgets; technology; early childhood.

Copyright (c) 2020 Kadek Hengki Primayana, Putu Yulia Angga Dewi

$\square$ Corresponding author :

Email Address : hengkiprimayana@gmail.com (Singaraja, Indonesia)

Received 2 August 2020, Accepted 7 August 2020, Published 11 August 2020 


\section{PENDAHULUAN}

Teknologi yang semakin maju yang ditandai dengan beredarnya barang-barang elektronik yang dapat membantu manusia, teknologi juga sangatlah pentagoni untuk mengakses informasi terbaru dari dalam negeri hingga di luar negeri, sekarang apapun yang terjadi di dunia diketahui dengan mudah dengan adanya teknologi yang terkoneksi internet yang sudah ada. Pesatnya perkembangan teknologi tampaknya tidak terhindarkan, bahkan teknologi kini telah menjadi objek kebutuhan manusia, pengembangan teknologi pada awalnya hanya sebagai alat untuk membantu melakukan bisnis. Semakin pesat berkembangnya teknologi, sektor pendidikan juga merasakan perkembangannya (Ngafifi, 2014). Saat ini, baik orang dewasa maupun anak-anak sangat membutuhkan teknologi. Karena teknologi yang digunakan sekarang sangat berbeda dengan teknologi yang awalnya diterapkan.

Di bidang pendidikan, teknologi biasanya digunakan untuk membantu media pengajaran, seperti audio-visual, video, dan lain-lain, serta platform dapat lebih banyak diterapkan di bidang pendidikan. Berdasarkan data dari Badan Pusat Statistik yang dimuat dalam penelitian Machmud (2018), sebesar 62,41 persen sekolah memanfaatkan teknologi informasi sebagai media untuk kegiatan belajar mengajar. Kehadiran media elektronik memainkan peran penting dalam proses pembelajaran PAUD dan kehadiran teknologi di sektor pendidikan membuat proses pembelajaran lebih menyenangkan. Selain itu, guru dapat lebih mudah mendistribusikan materi kepada anak-anak, sehingga memudahkan pencapaian prestasi pendidikan. Media e-learning yang digunakan lebih menarik bagi anakanak, sehingga akan memudahkan anak-anak untuk memahami tujuan pembelajaran yang dijelaskan oleh guru. Penggunaan media e-learning ini memang sangat bermanfaat bagi proses pembelajaran. Selain pendidikan, penggunaan teknologi juga bisa dirasakan di lingkungan sekitar, seperti penggunaan gawai.

Gawai disebut semua kalangan, terutama teknologi yang akrab bagi masyarakat luas. Gawai adalah perangkat elektronik kecil dengan tujuan dan fungsi tertentu, yang dapat mengunduh informasi terbaru, sehingga menjadikan kehidupan manusia praktis (Setianingsih, 2018). Gawai diketahui memiliki banyak jenis dan kegunaan, dan sangat menarik untuk anak-anak. Kami sangat akrab dengan penggunaan gawai pada anak-anak. Gawai saat ini memiliki beragam aplikasi, mulai dari game bertema belajar, hingga aplikasi yang dapat menghibur anak-anak saat bermain (Novitasari \& Khotimah, 2016). Namun kecendrungan penggunaan gawai pada anak yang tidak tepat akan menjadikan anak kurang perduli dengan kesehatan dan teman-teman yang ada di lingkungan sekitarnya. Saat ini banyak orang tua yang kurang perduli dengan intensitas penggunaan gawai pada anaknya. Pengasuhan anak juga lebih diberikan kepada orang lain. Hal ini menunjukan pendapat yang sama dengan observasi di lapangan bahwa memang benar lebih banyak orang tua mengizinkan anaknya menggunakan gawai sebagai teman bermainnya agar anak lebih mudah bermain tanpa harus dicari anak hanya akan berada di rumah. Hal ini akan mengakibatkan kurangnya interaksi anak dengan orang lain yang akan mengakibatkan anak kurang perduli dengan orang lain yang ada di sekitarnya. Ketika anak bertemu dengan temannya anak akan tidak terbiasa bermain dengan leluasannya karena memikirkan permainan yang lebih asik di gawainya.

Gawai yang digunakan oleh para kelompok anak usia dini memiliki dampak negatif yang akan mengakibatkan semakin memprihatinkan perkembangan anak, anak-anak yang terlalu sering beradaptasi dengan gawai akan lebih mudah menemukan fitur-fitur yang belum sepatutnya ditonton oleh anak sehingga akan menganggu perkembangan anak, fiturfitur tersebut jika belum difilter dengan usia anak juga akan mengakibatkan gangguan pada psikologis anak itu sendiri (Novitasari \& Khotimah, 2016). Pendampingan orang tua sangatlah diperlukan oleh anak dalam menggunakan gawai. Pada penelitian Delima et al. (2015) menemukan bahwa penggunaan perangkat teknologi terutama pada anak untuk game yakni $(94 \%)$ orang tua menyatakan bahwa anak mereka sudah terbiasa menggunakan 
perangkat teknologi untuk bermain game tanpa adanya bantuan dari orang tuanya untuk mencarikan aplikasi yang diinginkan anak. Anak membutuhkan waktu untuk bermain game $(63 \%)$ selama 30 menit untuk sekali bermain game dan (15\%) menggunakan waktu 30-60 menit untuk sekali bermain game namun jika tidak ada pengawasan intensitasnya bias semakin tinggi. Di Indonesia, gawai dapat digunakan dalam bentuk ponsel pintar, laptop, tablet, komputer, kamera, dan lain-lain. Namun, anak-anak berusia 5-6 tahun lebih terbiasa dengan ponsel pintar dan tablet yang digunakan untuk bermain atau belajar menggunakan media e-learning.

Fungsi setiap gawai itu berbeda-beda, seperti smartphone kegunaannya dapat menghubungi seseorang dari jarak yang dekat hingga yang jauh sehingga seberapa jauh jarak orang yang akan kita jangkau maka akan terasa dekat jika dapat berkomunikasi menggunakan gawai. Dengan keunggulan gawai yang begitu banyak, ketertarikan masyarakat untuk menggunakan semakin meningkat. Faktanya gawai tidak saja dikenal dikalangan remaja (usia 12-21 tahun), dewasa atau lanjut usia (usia 60 tahun keatas), namun dikenal juga pada anak-anak (usia 7-11 tahun) dan gawai juga sudah diperkenalkan oleh anak (usia 3-6 tahun) yang seharusnya belum bisa dikenalkan namun sekarang sudah tidak asing lagi bagi anak umur 3-6 tahun ini (Novitasari \& Khotimah, 2016). Sudah hal biasa pada saat ini mengetahui penggunaan gawai pada anak, selain gawai dengan berbagai fungsi dan aplikasi, anak-anak dapat menggunakan gawai untuk bermain game tanpa menghabiskan banyak energi. Bahkan sekarang, gawai bisa menjadi teman manusia.

Pengasuhan orang tua terhadap anaknya mendasari penggunaan gawai oleh anak usia dini. Jika orang tua yang memiliki pola asuh otoriter kepada anaknya atau sering kita ketahui dengan orang tua yang taat pada aturan dan nilai-nilai yang berlaku akan cenderung tidak memberikan penggunaan gawai bagi anaknya. Pendapat Suryameng (2019) menyatakan bahwa ketika anak mengaplikasikan gawai hendaknya perlu ada pendampingan pada anaknya untuk bermain menggunakan gawai, sehingga orang tua dapat memilah fitur-fitur yang digunakan oleh anak, hal tersebut yang diterapkan oleh pola asuh otoriter. Sedangkan orang tua yang memilih penerapan pola asuh demokratis memberikan gawai sejak dini pada anaknya, karena mereka beranggapan bahwa gawai mempermudah anak dalam bermain dan orang tua juga akan dipermudahkan untuk beraktifitas, tetapi yang memiliki penerapan demokratis sering membatasi terhadap penggunaan gawai untuk anak jika melampaui batasnya (Fadzil et al., 2016). Selain itu jika memiliki penerapan pola asuh permisif lebih membebaskan penggunaan gawai pada anaknya tanpa adanya pengawasan dan kontrol penggunaan kepada anaknya yang menurut orang tua akan meringankan dan memberikan kebebasan orang tuanya dalam melaksanakan aktivitas (Chusna, 2017). Tipe pola asuh sangat mempengaruhi karakteristik dan perkembangan anak terhadap penggunaan media elektronik. Disamping itu harapan dari banyak orang tua kepada anak salah satunya meningkatkan minat dan termotivasi untuk belajar, pada saat anak memiliki minat dan motivasi tinggi materi pembelajaran akan dengan mudahnya untuk dimengerti (Aulina, 2018).

Namun, kita tidak dapat menghindari efek buruk pada anak-anak. Dampak yang sering kita temui di lapangan adalah cara berpikir, dan karena ketergantungan pada penggunaan gawai, perilaku sehari-hari anak-anak akan terganggu, sehingga anak-anak menggunakan gawai lebih intens. Proses berinteraksi dengan teman-teman di sekitar juga akan lebih tidak efektif, karena hanya menggunakan gawai untuk bermain dan tidak bertukar salam dengan subjek. Selain itu, dampak konten yang ada pada gawai sangat berbahaya, karena konten dalam gawai tidak difilter untuk anak-anak dan orang dewasa. Jika konten yang dilihat oleh anak-anak tidak boleh ditampilkan dengan risiko membahayakan mental anak, tentu saja sangat berbahaya.

Menurut penelitian yang dilakukan oleh Sujianti (2018) menyatakan bahwa pada saat anak bermain gawai, mereka akan memilih bermain pada gawai yang disukainnya. Penelitian lain juga mengungkapkan bahwa Indonesia merupakan negara yang aktif dalam 
penggunaan sosial media. Indonesia mempunyai 79,7\% user aktif dan mengalahkan Filipina $(78 \%)$, Malaysia $(72 \%)$, Cina $(67 \%)$. Penggunaan gawai pada usia 5 tahun yaitu $38 \%$ pada tahun 2011, menjadi 72\% pada tahun 2013, pada tahun 2015 yaitu 80\%. Anak banyak menggunakan gawai sebagai sarana bermain, 23\%, sedangkan dari $82 \%$ orang tua melaporkan bahwa mereka online setidaknya sekali dalam seminggu data tersebut menunjukan bahwa memang benar penggunaan gawai sangatlah digemari baik dari orang dewasa, anak-anak maupun lansia (Zubaidah, 2017). Namun untuk mendukung upaya pendidikan anak usia dini sulit terlepas dalam penggunaan teknologi terutama gawai.

Disamping memiliki dampak negatif tetapi gawai tetap dapat menawarkan kemudahan dan berbagai variasi dalam proses anak mempelajari banyak hal (Alia \& Irwansyah, 2018). Menurut penelitian yang dilakukan Machmud (2018) menyebutkan bahwa dampak positif dari penggunaan gawai, khususnya oleh anak diantaranya dapat melatih daya ingat dan pemahaman anak dalam berilmu, misalnya pada penambahan kosa kata anak, dengan adanya aplikasi yang menarik dapat membuat anak lebih tertarik dalam belajar karena dilengkapi dengan berbagai musik dan gambar. Anak-anak juga tidak membutuhkan waktu yang lama untuk memahami suatu materi.

Para orang tua mengetahui dan percaya pada manfaat gawai, terutama di bidang pendidikan, teknologi ini digunakan sebagai media pembelajaran elektronik. Penelitian oleh Tirtayani et al. (2017) menyatakan bahwa media elektronik merupakan media yang tepat dan baik untuk merangsang anak dalam melakukan proses belajar, alat pembelajaran yang dimanipulasi semenarik mungkin dapat meningkatkan minat anak serta dapat mempengaruhi pikiran, perasaan, perhatian dan sikap siswa sehingga memberikan dampak yang positif dari proses dan tujuan pembelajaran. Selain itu dengan memanipulasi media dalam bentuk animasi bergerak maupun audio visual anak lebih mengerti dan tujuan pembelajaran mudah tercapai. Penggunaan informasi dan teknologi juga menjadi tuntunan. Namun untuk merancang media pembelajaran elektronik memerlukan kemampuan khusus ini yang menimbulkan berbagai pandangan mengenai penggunaanya. Menurut Amaliah \& Setyowati (2019) bahwa orang tua memiliki pemahaman mengenai penggunaan media elektronik sangat berguna dan memudahkan pekerjaan sehingga mereka cendrung akan memiliki motivasi yang tinggi dalam belajar. Pemahaman yang baik dari orang tua ini tidak terlepas dari faktor personal yang dimilikinya seperti pendidikannya.

Berbeda dengan pemahaman itu, Annisa et al. (2019) menyatakan jika orang tua memiliki pemahaman yang baik terkait penggunaan media elektronik sebagai media pembelajaran akan memiliki pandangan bahwa jika penggunaan media elektronik mengarah pada pembelajaran yang memiliki dampak positif orang tua akan memiliki pandangan dan memberikan penggunaan media elektronik secara tepat, tetapi orang tua juga berhak untuk melarang penggunaan media pembelajaran elektronik yang tidak mendukung proses pembelajaran hal tersebut dinilai sangat penting karena mampu menentukan masa depan dari anak. Berdasarkan pemaparan pada kajian tersebut, kajian ini meneliti seberapa besar intensitas yang dihasilkan oleh anak anak dalam penggunaan gawainya yang didasari oleh pola asuh orang tua yang diterapkan dirumah.

Menurut Zulfitria (2018) untuk mengurangi penggunaan gawai pada anak dapat ditentukan dengan pola asuh yang diterapkan oleh orang tua, khususnya ketika anak sedang menggunakan gawainya. Orang tua hendaknya memberikan pengertian khusus mengenai cara menggunakan gawai itu sendiri sehingga anak dapat membatasi penggunaan gawainya tersebut. Anak-anak yang orangtuanya kekurangan informasi dapat dengan mudah menyalahgunakan gawai yang mereka miliki, sehingga anak-anak lupa waktu untuk memenuhi kewajiban akademik mereka sebagai siswa atau memikul kewajiban di rumah. Hal-hal kecil seperti ini dapat membantu mengatasi penggunaan gawai yang tidak penting bagi anak-anak. 


\section{METODOLOGI}

Pendekatan yang digunakan dalam penelitian ini merupakan pendekatan kuantitatif dengan metode penelitian survei dengan alasan semua anggota sampel atau responden dalam penelitan survei akan menjawab pernyataan yang sama yang telah diberikan saat pengambilan data yang sudah terlebih dahulu diuji oleh judges.

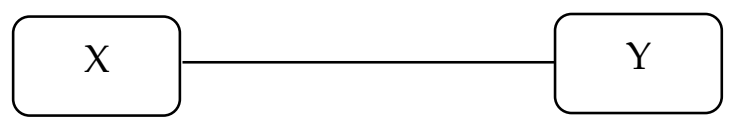

Gambar 1. Desain Penelitian

Penelitian ini mengukur nilai variabel, menguji hipotesis tentang perilaku, karakteristik objek, yang ada di lapangan untuk mendapatkan data yang terjadi pada masa lampau atau saat ini yang secara detail dan actual. Penelitian ini pada umumnya adalah penelitian korelasi. Pada penelitian ini menggunakan metode korelasi dan ex-post facto. Variabel pada penelitian ini adalah pola asuh demokratis dan intensitas penggunaan gawai.

Tabel 1. Hubungan Antar Variabel

\begin{tabular}{cc}
\hline & Intensitas Penggunaan Gawai $(\mathrm{Y})$ \\
\hline Pola Asuh Demokratis $(\mathrm{X})$ & $\mathrm{X}, \mathrm{Y}$ \\
\hline
\end{tabular}

Populasi penelitian ini adalah orang tua anak didik taman kanak-kanak yang ada di wilayah Kabupaten Buleleng, dengan jumlah 5.137 orang tua murid. Sampel merupakan bagian dari jumlah dan karakteristik yang dimiliki oleh populasi. Sampel dalam penelitian ini menggunakan teknik multistage random sample yang memadukan dua teknik sampling dengan jumlah 126 namun yang bersedia menjadi responden 119 orang tua anak yang tersebar pada 10 TK di Kabupaten Buleleng yang tersebar di seluruh kecamatan yang ada di Kabupaten Buleleng.

Selanjutnya untuk menganalisis data yang digunakan adalah Uji Validitas dengan melihat korelasi pearson product moment (r). Uji Reliabilitas dilakukan dengan menguji statistic Cronbach's alpha (a), dan Uji Normalitas menggunakan uji Chi Kuadrat. Uji liniearitas dengan melihat deviadition for linearity, untuk mengetahui hubungan antar variabel satu dengan yang lainnya dilakukan analisis menggunakan teknik korelasi product moment.

\section{HASIL DAN PEMBAHASAN}

Untuk memenuhi uji hipotesis, perlu dilakukan uji normalitas data dan uji liniearitas instrumen penelitian terlebih dahulu. Dalam analisis ini digunakan analisis Chi Kuadrat $\left(\mathrm{x}^{2}\right)$, dengan kriteria penilaian adalah jika $\chi^{2}$ hitung $<\chi^{2}$ tabel maka sebaran data berdistribusi normal. Selanjutnya dilakukan uji linieritas. Kriteria yang digunakan adalah nilai signifikansi deviation from linearity $>0,05$ sebagai hubungan yang linier. Berikut rangkuman hasil uji normalitas sebagaimana dapat disajikan pada Tabel 2.

Tabel 2. Hasil Uji Normalitas Tabel Kerja Chi Square Skor Intensitas Penggunaan Gawai

\begin{tabular}{lrrrrr}
\hline Interval Nilai & fo & fh & fo-fh & (fo-fh) $^{\mathbf{2}}$ & ${\text { (fo-fh) } \mathbf{~}^{\text {/fh }}}$ \\
\hline $40,83-45,70$ & 4 & 2,71 & 1,29 & 1,6641 & 0,614059041 \\
\hline $45,70-50,58$ & 11 & 16,17 & $-5,17$ & 26,7289 & 1,652993197 \\
\hline $50,58-55,45$ & 37 & 40,61 & $-3,61$ & 13,0321 & 0,320908643 \\
\hline $55,45-60,33$ & 52 & 40,61 & 11,39 & 129,7321 & 3,194585078 \\
\hline $60,33-65,20$ & 15 & 16,17 & $-1,17$ & 1,3689 & 0,084656772 \\
\hline $65,20-70,07$ & 0 & 2,71 & $-2,71$ & 7,3441 & 2,71 \\
\hline & 119 & & & & 8,57720273 \\
\hline
\end{tabular}


Dari hasil analisis pada Tabel 2 diperoleh Chi Kuadrat hitung ( $\chi 2$ hitung $=8,58)$ kemudian selanjutnya nilai tersebut dibandingkan dengan Chi Kuadrat tabel dengan taraf signifikan 5\% dan dk= jumlah baris-1 = 6-1=5, didapatkan harga Chi Kuadrat tabel sebesar 11,07 . Hal tersebut menunjukan bahwa $\chi^{2}$ hitung $<\chi^{2}$ tabel yang berarti data intensitas penggunaan gawai berdistribusi normal. Selanjutnya dilanjutkan dengan langkah-langkah uji Chi Square ( $\left.\chi^{2}\right)$ skor pola asuh demokratis dapat disajikan pada Tabel 3.

Tabel 3. Hasil Uji Normalitas Tabel Kerja Chi Square Skor Pola Asuh Demokratis

\begin{tabular}{crrrrr}
\hline Interval Nilai & fo & fh & fo-fh & (fo-fh) $^{\mathbf{2}}$ & (fo-fh) ${ }^{\mathbf{2}} \mathbf{f h}$ \\
\hline $66,81-72,86$ & 3 & 2,71 & 0,29 & 0,084 & 0,03103321 \\
\hline $72,86-78,91$ & 14 & 16,17 & $-2,17$ & 4,709 & 0,291212121 \\
\hline $78,91-84,96$ & 32 & 40,61 & $-8,61$ & 74,13 & 1,825464171 \\
\hline $84,96-91,01$ & 54 & 40,61 & 13,39 & 179,3 & 4,414974144 \\
\hline $91,01-97,06$ & 16 & 16,17 & $-0,17$ & 0,029 & 0,00178726 \\
\hline $97,06-103,11$ & 0 & 2,71 & $-2,71$ & 7,344 & 2,71 \\
\hline \multicolumn{7}{r}{} & 119 & & & 9,274470908 \\
\hline
\end{tabular}

Sesuai hasil analisis sebagaimana tertera pada Tabel 3 diperoleh Chi Kuadrat hitung ( $\chi 2$ hitung $=9,27$ ) selanjutnya nilai tersebut dibandingkan dengan Chi Kuadrat tabel dengan taraf signifikan $5 \%$ dan $\mathrm{dk}=$ jumlah baris-1 $=6-1=5$, didapatkan harga Chi Kuadrat tabel sebesar 11,07. Hal tersebut menunjukan bahwa $\chi^{2}$ hitung $<\chi^{2}$ tabel yang berarti data pola asuh demokratis adalah normal.

Uji linearitas dilakukan dengan kriteria apabila nilai signifikansi Deviation from linearity $>$ 0,05 maka hubungan antara variabel bebas dengan variabel terikat adalah linier. Hasil uji linearitas disajikan pada Tabel 4.

Tabel 4. Hasil Uji Linieritas

\begin{tabular}{|c|c|c|c|c|c|c|c|}
\hline & & & $\begin{array}{l}\text { Sum of } \\
\text { Squares }\end{array}$ & $\mathrm{df}$ & $\begin{array}{l}\text { Mean } \\
\text { Square }\end{array}$ & $\mathrm{F}$ & Sig. \\
\hline \multirow{5}{*}{$\begin{array}{l}\text { Intensitas } \\
\text { Penggunaan } \\
\text { Gawai * } \\
\text { Pola Asuh } \\
\text { Demokratis }\end{array}$} & \multirow{3}{*}{$\begin{array}{l}\text { Between } \\
\text { Groups }\end{array}$} & (Combined) & 1581.827 & 16 & 98.864 & 3.639 & .000 \\
\hline & & Linearity & 967.312 & 1 & 967.312 & 35.603 & .000 \\
\hline & & $\begin{array}{l}\text { Deviation } \\
\text { from Linearity }\end{array}$ & 614.515 & 15 & 40.968 & 1.508 & .116 \\
\hline & Within Groups & & 2771.282 & 102 & 27.169 & & \\
\hline & Total & & 4353.109 & 118 & & & \\
\hline
\end{tabular}

Dari hasil perhitungan menggunakan bantuan SPSS di dapatkan hasil analisis uji linieritas intensitas penggunaan gawai terhadap pola asuh dengan melihat hasil signifikansi linearity 0,116 yang merupakan lebih besar dengan taraf signifikansi 5\% (0,05), bahwa variabel intensitas penggunaan gawai terhadap pola asuh memenuhi uji linieritas. Selanjutnya hasil perhitungan analisis korelasi Product Moment menunjukan koefisien korelasi sebesar 0,4714. Selanjutnya dikonsultasikan pada $r$ tabel dengan $N=119$ dan taraf signifikansi 5\% diperoleh sebesar 0,179 ini menunjukan bahwa adanya hubungan yang signifikan.

Hasil analisis ini juga berkaitan dengan hasil penelitian Zaini \& Soenarto (2019) menurut penelitian yang diteliti menyatakan bahwa tingginya penggunaan gawai pada anak usia 4-6 tahun disebabkan oleh pola asuh dalam penggunaan teknologi pada anak usia dini. Penggunaan gawai memberikan dampak pada perkembangannya. Penggunaan media elektronik anak sering memilih permainan dan terlalu ekstream, dalam permainan ini yang perlu orang tua awasi dalam penggunaan media elektronik untuk anak usia dini. Berdasarkan hasil penelitian menunjukan bahwa $87 \%$ orang tua beranggapan bahwa alat 
elektronik yang digunakan anak berupa smartphone dan tablet yang mudah dibawa kemana-mana.

Kecenderungan anak dalam menggunakan gawai untuk bermain lebih tinggi dari penggunaan untuk edukasi hal tersebut perlu diperhatikan oleh orang tua. Orang tua harus tegas mendidik jika anak terlalu berlebihan menggunakan gawai, karena tanpa pengawasan orang tua anak akan melihat yang tidak baik untuk kesehatan psikologisnya. Sementara $66 \%$ orang tua menyatakan jika media elektronik dipergunakan dengan bijak dalam proses pembelajaran seperti menulis, bergambar dan menyanyi yang dapat mengasah kemampuan anak sangatlah membantu tujuan pendidikan. Sementara pada penelitian yang dilakukan, bahwa adanya hubungan yang positif dan signifikan antara pola asuh orang tua akan terhadap intensitas penggunaan gawai dengan hasil yang menunjukan nilai rata rata 55,78. Nilai rata-rata tersebut menunjukan adanya perbedaan yang cukup besar dibandingkan dengan nilai rata-rata pada kuesioner intensitas penggunaan gawai yang diperoleh 84,96. Rendahnya nilai rata-rata intensitas penggunaan gawai yang disebabkan oleh kurangnya dukungan dari orang tua. Pengasuhan yang diterapkan dalam hal ini sangatlah penting karena akan mampu menentukan masa depan anak usia dini, pendapat ini juga sejalan dengan penelitian yang dilakukan oleh Annisa et al. (2019).

Pada analisis penelitian ini pada variabel pola asuh memiliki skor yang poin yang tinggi sebesar 55,78 yang menunjukan bahwa sebagian orang tua setuju dengan memberikan anaknya gawai tanpa melaksanakan pengawasan. Sedangkan penelitian yang dilakukan oleh Nurhaeda (2018) menyatakan bahwa kebanyakan pendapat orang tua lebih mengarah pada pendapat penggunaan yang menimbulkan dampak negatif bagi perkembangan anak diantaranya tingkat radiasi gelombang elektromagtik yang dirasakan anak lebih tinggi jika terlalu banyak menggunakan gawai, selain itu daya konsentrasi anak akan terganggu dengan adanya permainan yang tidak ada unsur dengan pembelajaran, namun efeknya tidak terlihat secara langsung. Hal ini merupakan sejalan dengan penelitian yang lebih mengarah pemberian penggunaan gawai pada anak. Tanpa disadari bahwa anak sudah banyak mengalami kecanduan dalam penggunaan gawai yang dilihat dari intensitas penggunaannya. Menurut penelitian Suryameng (2019) ketika anak memanfaatkan penggunaan benda elektronik tentu harus adanya pengawasan oleh orang tua, orang tua memang sangat penting atau menjadi tombak perkembangan anaknya sendiri. Perilaku orang tua juga akan mudah ditiru oleh anaknya.

Pola orang tua angkat sangat penting untuk mengurangi penggunaan gawai, terutama ketika anak-anak menggunakan gawainya. Orang tua harus memberikan pengetahuan khsusus tentang menggunakan gawai itu sendiri dan orang tua dapat membatasi penggunaan gawai ini. Memberikan pengetahuan tentang penggunaan gawai harus dilakukan sesegera mungkin agar anak dapat memahami apa dampak positif dan dampak negative Ketika menggunakan perangkat itu. Anak-anak yang kekurangan informasi dan bimbingan orang tua pada penggunaan gawai, akan salah dalam menggunakan gawai yang mereka miliki, anak-anak akan lupa waktu dalam melakukan tugas mereka. Kondisi menunjukkan pola pengasuhan sangat penting dalam mengurangi intensitas penggunaan gawai.

Dari hasil ini dapat dijadikan bahan pertimbangan kepada Lembaga yang memiliki kewenangan sebaiknya memberikan parenting education ataupun sosialisasi kepada orang tua mengenai dampak penggunaan gawai dengan intensitas tinggi. Sehingga orang tua mengetahui dampat penggunaan gawai terhadap perkembangan anak dan bagaimana seharusnya orang tua memberikan gawai kepada anak usia dini. Apabila orang tua mendampingi, mendidik, mengajarkan dan membuat peraturan dalam menggunakan gawai pada anak, maka perkembangan sosial anak akan berkembang dengan baik. Lembaga yang memiliki wewenang sebaiknya juga melakukan kegiatan seminar untuk para orang tua mengenai dampak gawai terhadap anak. Selain itu menjelaskan kegiatan fisik yang 
sebaiknya dilakukan sebanyak-banyaknya agar anak-anak bisa melupakan kegiatan yang dilakukan dengan gawai.

Dari hasil penelitian menurut Al-Ayouby (2017) yang menyatakan bahwa intensitas penggunaan gawai dapat dilihat dari seberapa lama penggunaan gawai dalam satu hari. Intensitas penggunaan yang tinggi akan mengarah pada kehidupan anak yang cenderung hanya bermain di dalam rumah dan tidak memperhatikan lingkungan di sekitarnya. Hal ini juga menunjukan bagaimana cara anak berperilaku terhadap orang yang berada disekitarnya. Penelitian ini memperoleh hasil memang benar terhadap hubungan yang positif antara variabel bebas dengan variabel terikatnya. Dalam hal ini perlunya upayaupaya untuk mengatasi seperti pengawasan penggunaan gawai pada anaknya, pemanfaatan penggunaan media elektronik yang lebih bijak. Oleh karena itu orang tua dituntut untuk lebih kreatif dalam mengasuh anak, mendidik anak serta memberikan waktu pendampingan anak dalam bermain tidak hanya memfasilitasi namun juga perlu adanya kontrol dari orang tua dan mengarahkan anak dalam bermain. Menjadi orang tua tidaklah mudah pada saat ini tidak hanya dibutuhkan kesabaran namun dibutuhkan juga kecakapan. Gawai memang dibutuhkan untuk sarana komunikasi namun gawai bukanlah benda segalanya yang dapat membantu gawai juga memiliki dampak baik positif maupun negatifnya.

\section{SIMPULAN}

Pola asuh orang tua sangat mempengaruhi intensitas penggunaan gawai pada anak usia dini. Selain itu, jika digunakan dengan benar, bantuan orang tua dengan penggunaan gawai juga akan berdampak positif, tetapi jika tidak dikendalikan, penggunaan gawai mungkin berdampak negatif pada anak-anak. Untuk mengatasinya perlu adanya pembatasan dan permainan yang kreatif yang diberikan kepada anak. Intensitas penggunaan gawai yang baik bagi anak seperti pemanfaatan penggunaan gawai untuk proses pembelajaran sangatlah baik dan membantu pemahaman anak karena disertakan dengan media yang menarik yang tentunya akan meningkatkan daya tarik anak dan rasa ingin tahunya akan media tersebut. Dalam penelitian ini, ditemukan korelasi positif dan signifikan antara pola asuh demokratis dengan intensitas penggunan gawai pada anak usia dini.

\section{UCAPAN TERIMA KASIH}

Peneliti mengucapkan terima kasih sedalam-dalamnya kepada Tuhan Yang Maha Esa atas berkat dan rahmatNya sehingga peneliti dapat melaksanakan penelitian dan menyelesaikan penelitian ini. Dinas Pendidikan Kabupaten Buleleng serta pihak sekolah serta para orang tua atas kerjasamanya selama peneliti melakukan penelitian.

\section{DAFTAR PUSTAKA}

Al-Ayouby, M. H. (2017). Dampak Penggunaan Gadget Pada Anak Usia Dini (Studi di PAUD dan TK. Handayani Bandar Lampung). http://digilib.unila.ac.id/27131/

Alia, T., \& Irwansyah, I. (2018). Pendampingan Orang Tua pada Anak Usia Dini dalam Penggunaan Teknologi Digital [Parent Mentoring of Young Children in the Use of Digital Technology]. Polyglot: Jurnal Ilmiah, 14(1), 65-78. https://doi.org/http://dx.doi.org/10.19166/ pji.v14i1.639

Amaliah, S., \& Setyowati, S. (2019). Persepsi Orang Tua Terhadap Penggunaan Gawai Pada Anak Usia Dini Di Tk Lab School Unesa Ketintang Surabaya. PAUD Teratai, 8(1). https://jurnalmahasiswa.unesa.ac.id/index.php/paud-teratai/article/view/27946

Annisa, A., Marlina, S., \& Zulminiati, Z. (2019). Hubungan Persepsi Orang Tua Tentang Dampak Smartphone Terhadap Perkembangan Sosial Pada Anak Di Kelompok Bermain Gugus I Kecamatan Nanggalo Kota Padang. Jurnal Ilmiah POTENSIA, 4(1), 59-66. https://doi.org/https://doi.org/10.33369/jip.4.1.59-66 
Aulina, C. N. (2018). Penerapan Metode Whole Brain Teaching dalam Meningkatkan Motivasi Belajar Anak Usia Dini. Jurnal Obsesi: Jurnal Pendidikan Anak Usia Dini, 2(1), 1-12. https://doi.org/https://doi.org/10.31004/obsesi.v2i1.1

Chusna, P. A. (2017). Pengaruh Media Gadget Pada Perkembangan Karakter Anak. Dinamika Penelitian: Media Komunikasi Penelitian Sosial Keagamaan, 17(2), 315-330. https:// doi.org/10.21274/dinamika.2017.17.2.315-330

Delima, R., Arianti, N. K., \& Pramudyawardani, B. (2015). Identifikasi Kebutuhan Pengguna Untuk Aplikasi Permainan Edukasi Bagi Anak Usia 4 sampai 6 Tahun. Jurnal Teknik Informatika Dan Sistem Informasi, https:// doi.org/https:// doi.org/10.28932/jutisi.v1i1.569

Fadzil, N. M., Abdullah, M. Y., \& Salleh, M. A. M. (2016). The Level Of Tolerance Sanctioning Children Using Gawais By Parents Lead To Nomophobia: Early Age Gawais Exposure. International Journal of Arts \& Sciences, 9(2), 615. http://www.universitypublications.net/ijas/0902/html/V6Z285.xml

Machmud, K. (2018). The Smartphone Use In Indonesian Schools: The High School Students' Perspectives. Journal of Arts and Humanities, 7(3), 33-40. https:// doi.org/http://dx.doi.org/10.18533/journal.v7i3.1354

Ngafifi, M. (2014). Kemajuan Teknologi Dan Pola Hidup Manusia Dalam Perspektif Sosial Budaya. Jurnal Pembangunan Pendidikan: Fondasi Dan Aplikasi, 2(1). https:// doi.org/https:// doi.org/10.21831/jppfa.v2i1.2616

Novitasari, W., \& Khotimah, N. (2016). Dampak Penggunaan Gadget Terhadap Interksi Sosial Anak Usia 5-6 Tahun. PAUD Teratai, 5(3). https://jurnalmahasiswa.unesa.ac.id/index.php/paud-teratai/article/view/17261

Nurhaeda, N. (2018). Dampak Penggunaan Gadget Pada Anak Usia Dini Dalam Pan-Dangan Islam Di Paud Terpadu Mutiara Hati Palu. ECEIJ (Early Childhood Education Indonesian Journal), 1(2), 70-78. https:// doi.org/10.31934/eceij.v1i2.518

Setianingsih, S. (2018). Dampak Penggunaan Gadget Pada Anak Usia Prasekolah Dapat Meningkatan Resiko Gangguan Pemusatan Perhatian Dan Hiperaktivitas. Gaster, 16(2), 191-205. https://doi.org/https:// doi.org/10.30787/gaster.v16i2.297

Sujianti, S. (2018). Hubungan Lama Dan Frekuensi Penggunaan Gadget Dengan Perkembangan Sosial Anak Pra Sekolah Di Tk Islam Al Irsyad 01 Cilacap. Jurnal Kebidanan, 8(1), 54-65. https://doi.org/https://doi.org/10.31983/jkb.v8i1.3735

Suryameng, S. (2019). Pendampingan Dialogis Orangtua Dalam Penggunaan Gadget Pada Anak Usia Dini. DUNIA ANAK: Jurnal Pendidikan Anak Usia Dini, 2(2), 40-49. https:// doi.org/https:// doi.org/10.31932/jpaud.v2i2.764

Tirtayani, L. A., Magta, M., \& Lestari, N. G. A. M. Y. (2017). Teacher Friendly E-Flashcard: A Development Of Bilingual Learning Media For Young Learners. Journal of Education Technology, 1(1), 18-29. https:/ / doi.org/http:/ / dx.doi.org/10.23887/jet.v1i1.10080

Zaini, M., \& Soenarto, S. (2019). Persepsi Orangtua Terhadap Hadirnya Era Teknologi Digital Di Kalangan Anak Usia Dini. Jurnal Obsesi: Jurnal Pendidikan Anak Usia Dini, 3(1), 254264. https://doi.org/https://doi.org/10.31004/obsesi.v3i1.127

Zubaidah, Z. (2017). Hubungan Durasi Penggunaan Gadget Terhadap Perkembangan Sosial Anak Prasekolah di TK PGRI 33 Sumurboto, Banyumanik. http:/ / eprints.undip.ac.id/55141/

Zulfitria, Z. (2018). Pola Asuh Orang Tua Dalam Penggunaan Smartphone Pada Anak Sekolah Dasar. Jurnal Holistika, 1(2). https://jurnal.umj.ac.id/index.php/holistika/article/view/2502 